\title{
Does Financial Literacy Effect to Performance and Sustainability of Culinary MSMEs in Greater Jakarta?
}

\section{Reny Fitriana Kaban1, Martina Safitry 2}

1Economics \& Business, Perbanas Institute, Jakarta, Indonesia 2Administration Science, IISMI STIAMI, Jakarta, Indonesia

\section{Info Article}

History Article:

Submitted: 12 March 2020

Revised: 11 June 2020

Accepted: 16 June 2020

\section{Keywords:}

Business Performance,

Culinary MSME, financial

literacy, sustainability.

\begin{abstract}
This research aims to find out whether financial literacy effects performance and sustainability of culinary MSME. Respondents are 100 managers or owners of culinary MSMEs in Greater Jakarta who are responsible for making decisions regards the business and selected by purposive sampling. Structured questionnaire consisted of type of quiz modified from the Basic Indonesian Financial Literacy Index to determine financial literacy and modification of the EFQM Excellence Model to measure performance based on the perception of how far the respondent reaches the indicators of business results. Questions of business sustainability is modified from the Triple Bottom Line reporting indicator to measure sustainability of business operations in terms of economic, environmental and social aspects. SEM model is used to analyze data. The result showed financial literacy has a significant effect to performance of culinary MSME as well as the performance has a significant effect to sustainability of culinary MSME. However, financial literacy does not have a significant effect to sustainability of culinary MSME. It is strongly recommended to management of culinary MSMEs to increase their management capacity in term of financial literacy especially ability to be engaged with digital and financial technology.
\end{abstract}

\section{Apakah Literasi Keuangan Mempengaruhi Kinerja dan Kelangsungan Hidup UMKM Kuliner di Jabodetabek?}

\begin{abstract}
Abstrak
Penelitian ini bertujuan untuk. mengetahui apakah literasi keuangan berpengarub terhadap kinerja dan keberlanjutan UMKM Kuliner. Responden adalah 100 orang manager dan atau pemilik. UMKM kuliner di Jabodetabek yang bertanggungjawab dalam pengambilan keputusan terkait bisnis mereka dan dipilih dengan purposive sampling. Kuesioner terstruktur terdiri dari pertanyaan yang dimodifikasi dari Basic Indonesian Financial Literacy Index untuk menentukan literasi keuangan dan modifikasi dari EFQM Excellence Model untuk mengukur kinerja berdasarkan persepsi seberapa jaub responden mencapai indikator hasil bisnis. Pertanyaan sustainability bisnis dimodifikasi dari pelaporan indikator Triple Bottom Line untuk mengukur keberlanjutan operasional bisnis dalam aspek ekonomi, lingkungan dan sosial. Model SEM digunakan untuk menganalisa data. Hasil menunjukkan literasi keuangan berpengaruh signifikan terbadap kinerja UMKM kuliner sebagaimana kinerja juga berpengaruh signifikan terhadap sustainability UMKM kuliner. Namun literasi kenangan tidak berpengarub signifikan terhadap sustainability UMKM kuliner. Sangat direkomendasikan bagi manajemen UKM kuliner untuk meningkatkan kapasitas manajemen mereka dalam bentuk literasi keuangan khususnya kemampuan yang berbubungan dengan digital dan teknologi keuangan.
\end{abstract}

How to Cite: Kaban R., F., \& Safitry, M. (2020). Does Financial Literacy Effect to Performance and Sustainability of Culinary MSMEs in Greater Jakarta? Ekonomi Bisnis, 25(1), 1-13 
Performance and growth of medium, small and micro enterprises (MSME) across the country have become a major concern for entrepreneurs, governments, venture capital companies, and investors as well as financial institutions and non-governmental organizations (Eniola \& Etenbag, 2016:32). This is due to MSME plays an important role and have a large contribution to the economy of a country, including Indonesia. Beside increasing the gross domestic product (GDP), MSMEs are able to absorb the domestic workforce and increase the public income. In other words, MSME plays a strategic role in combating poverty and unemployment. The Ministry of Cooperatives and SMEs in the last 5 years has noted that the contribution of MSMEs to GDP reached $7.1 \%$. While in terms of labor absorbs $10.7 \%$ or about 12 million in total from the workforce (Aryco, 2017).

From 56.4 million of MSMEs in Indonesia, $70 \%$ of them consist of food or culinary MSMEs. In West Java itself, data from Central Statistics Agency (BPS) in 2014 showed that the food and beverage industry got first rank in terms of number, which is 4,023 MSMEs. This data further proves the potential of culinary MSMEs as an economic driver for community is very big. Since 2012 culinary MSMEs have been included by the Ministry of Tourism and Creative Economy as creative industry subsectors in Indonesia. This is because since 2010 the culinary industry has contributed to an increase in the number of companies, and contributed to the GDP with a proportion of more than $7 \%$ through an increase in the contribution of exports in 2011-2013 totaling 29.7\% (Aribawa, 2016:2).

However, several factors were found as constrains for the improvement of MSME performance and sustainability. Research results of Bank Indonesia mention that there are four (4) major obstacles that must be faced by
MSME, namely limited working capital, human resources, product innovation and technology also marketing. The capital factor is usually the most frequently complained of. Difficulties in getting capital are caused by weaknesses in accessing financial institutions, one of which is banking. The level of financial literacy of MSME is the key to MSME's access to financial institutions in their efforts to finance and increase their business capital.

Unfortunately, according to OJK (Otoritas Jasa Keuangan) data in 2014, the level of financial literacy of MSME in Indonesia is still very low, only $15.68 \%$. Likewise, the lending to MSME is only $18 \%$ of total loans (Rp. 635 trillion from Rp. 3,500 trillion). This value is very small when compared to the number of MSME business actors, which is 56.4 million, and around $70 \%$ of this number has not received access or banking financing (Sarwono, 2015:5). The low level of financial literacy at MSMEs has an impact on credit absorption by the banking sector. This is in accordance with the results of a survey conducted by BI "Research Profile of MSME in Indonesia" that one of the banking constraints in channeling credit to MSME is the limited information of banking about potential MSME and the eligibility of MSME.

A study will be meaningful if it has some purposes. Firstly this study aims to find out whether financial literacy effect to performance and sustainability of culinary MSME, especially in Greater Jakarta. Secondly, the outcome of this research will have an impact on various sectors such as the business sector (both the owners and managers of MSME) also government and private sectors as stakeholders (managers of financial institutions).

Furthermore, the impact of the results of this research, first, it is expected an increase in knowledge for culinary MSME owners and 
managers regarding financial literacy, so that they are able to make appropriate management and financial decisions for the success and sustainability of the business. The real impact for culinary MSME is that when conducting this research they indirectly received education about what is financial literacy, why and how it can affect business performance and sustainability. Next, the impact of this research to stakeholders will be an input on the importance of increasing financial literacy for businesses, especially culinary MSME. By this research it is expected that stakeholders can map the level of financial literacy of culinary MSME so that they can respond quickly to provide appropriate programs in order to facilitate their access to services and financing in financial institutions. At the end, capital constraints which are the main factors in improving business performance and sustainability can be resolved.

Financial literacy according to Manurung \& Barlian (2009:14) is a set of skills and knowledge that enables an individual to make effective decisions with all their financial resources. As stated by Hung, Parker and Yoong in Eniola and Etenbang's research (2015:33) that financial literacy is defined differently as specific forms of knowledge, abilities or skills to apply perceived knowledge, good financial behavior, and even financial experience.

Furthermore Garman \& Forgue in Eniola and Etenbang's study (2016:33) mentioned financial literacy as sufficient knowledge about personal financial facts and is the key to personal financial management. The same thing was also stated by Lusardi and Mitchell (2013:2) that financial literacy consists of a number of abilities and knowledge about finances owned by someone to be able to manage or use some money to improve their living standard.
While the definition of financial literacy specifically addressed to managers and business people, in this case MSME is as someone who knows what financing decisions are most suitable for business performance at various stages of business growth; knows where to get the most appropriate products and services; and interacts and has trust with product suppliers (USAID, 2009:5). Likewise, Marriott and Mellett in Eniola and Etenbang's research (2016:33) defines financial literacy as the ability of managers to understand and analyze financial information and act accordingly.

Assessment of financial literacy in culinary MSME in this study refers to a collaborative project called Support for Economic Analysis Development in Indonesia (SEADI) conducted by Definit, the Financial Services Authority (OJK) and USAID (Santoso, 2013:38). Where the project produced findings called the Indonesian Basic Financial Literacy Index. The questions on the index were modified to suit the research unit which is culinary MSME. One example of the questions on the questionnaire is "Do you have to save some money when opening an account at a bank? ".

The term of business performance according to Wibowo in research of Febriatmoko and Raharjo (2015:141) comes from the word performance as a result of work or work performance. Actually, performance has broad meaning, not only the work result, but how the work process takes place. As for other opinions expressed by Armstrong and Baron in Eniola \& Etenbang (2016:32), performance is the result of work that has a relationship with the strategic objectives of the organization, customer satisfaction, and contributing to the economy.

Ali in Aribawa (2016:4) suggested MSME performance was analyzed using an approach based on the following three assumptions, 
namely: 1) Measurement of MSME performance is often difficult to do quantitatively, due to limited resources (financial and labor understanding). 2) Generally, performance assessment is by looking at complex financial indicators, so this does not fully show the actual conditions that occur in the business. 3) Performance measurements that are often used are relatively only appropriate when used for large companies that are structured in the company's management. So, a non-cost performance measures approach was formulated to measure MSME performance as a measurement of financial and non-financial performance.

One of the current trend performance assessment indicators and approach is the Excellence Model, established by the European Foundation for Quality Management (EFQM), is a tool designed for comprehensive assessment of a company and its performance. It emphasizes the role of leadership in the organization, its corporate strategy and policy, the impact on employees, as well as resources and partnerships used as basic presumptions of the proper functioning of processes. The outcome of these processes is expressed by a relationship with customers and employees and their relationship to the company, which can be regarded as the results of its core activities. This EFQM Model puts the greatest emphasis on the principle of continuous improvement (Šenova \& Antasova, 2015: 185).

EFQM Excellence Model is suitable to assess the nonfinancial aspects of the performance of a company, analyze the current situation in the company, find areas for potential improvements, reveal weaknesses in its operations which should be eliminated in order to make the company more effective and ultimately economically efficient. Using this method, it was confirmed that the company performs and is managed well also the performance is improving. Therefore, in this study, the assessments of performance in culinary MSME refer to the perception of the business result approach adapted from EFQM excellence model. One example of a statement on the questionnaire is "The company has indicators to measure productivity and overall operational performance".

The concept of sustainability at the micro business level, in this case the MSME business, has not had a standard definition yet. This is consistent with what was said by Salimath \& Jones III in Supriyadi (2013:13): "There is no consensus on a unified definition of sustainability. Futhermore, measurement and interpretation of this construct appears to be idiosyncratic to specific aims or research interest. Literature review study which was conducted by Supriyadi (2013:14) entitled "Concepts and Models of Corporate Sustainability Measurement" states that if corporate sustainability is measured based on economic dimensions, it will be reflected in the degree to which the company is able to earn profits in the long run and the extent of profit growth trends from investment activities undertaken from time to time. If in the long run the company is able to profit stably, then this indicates the company has good sustainability. Likewise, with its growth, if profits always experience growth, the sustainability of the company is said to be very good based on the economic dimension.

Based on research conducted by Manurung and Barlian (2012:788), MSME in the creative industries tend to have a short-term orientation in decision making in their business. This can be seen from the absence of continuous innovation concepts and inconsistent core business activities. In the end, the development of the long-term performance of MSME tends to be stagnant and not well directed. 
Significant barriers of MSMEs' sustainable growth of its performance throughout the developing countries are the lack of knowledge, skills, attitudes and awareness to overcome and direct their organization's finances in a transparent, hard and professional manner. Joo and Grable in Eniola \& Etenbang (2016:32) state that the reasons why business people make inappropriate, inadequate and ineffective financial decisions are due to lack of personal financial knowledge, lack of time to learn about personal financial management, complexity in financial transactions and various choices in financial products/services. Lack of business management skills can increase financial barriers for MSME. A low level of financial literacy (such as lack of banking financing provision and loan application procedures) can reduce the level of MSME performance. The research framework of this study can be seen in Figure 1.

According to previous explanations, business sustainability at MSME in this study was measured through Triple Bottom Line (TBL) reporting (Supriyadi, 2013:13). This is a result of the organization's ability to maintain the continuity of its business operations, and the first bottom line is proper financial sustainability, therefore the question "Is your business has experienced continuous profit growth for the past 3 years? addressed to the MSME. The second and third bottom line whether the business has positive impact on the ecological social system. So, the questions to be given to the MSME for its sustainability "Is there an allocation of costs incurred as a commitment to the environment and social problem?

Previous research on the effect of Financial Literacy to Performance and Sustainability of MSME was conducted by Aribawa (2016), with the title "The Effect of Financial Literacy on MSME Performance and Sustainability in Central Java". The research development was carried out by Rahayu (2017) with the title "The Effect of Financial Literacy on the Performance and Sustainability of MSME in Surabaya". However, what distinguishes this study from the two previous studies is from the methodology where the indicators used to measure performance and sustainability in Ariwibawa (2016) and Rahayu (2017) research use the Balance Score Card. In this study there is development through modification of the scope of the measuring, more up-to-date, which is Excellent Model from EFQM for measuring performance and Triple Bottom Line for measuring sustainability. In addition, the sample are larger in both the number and the region.

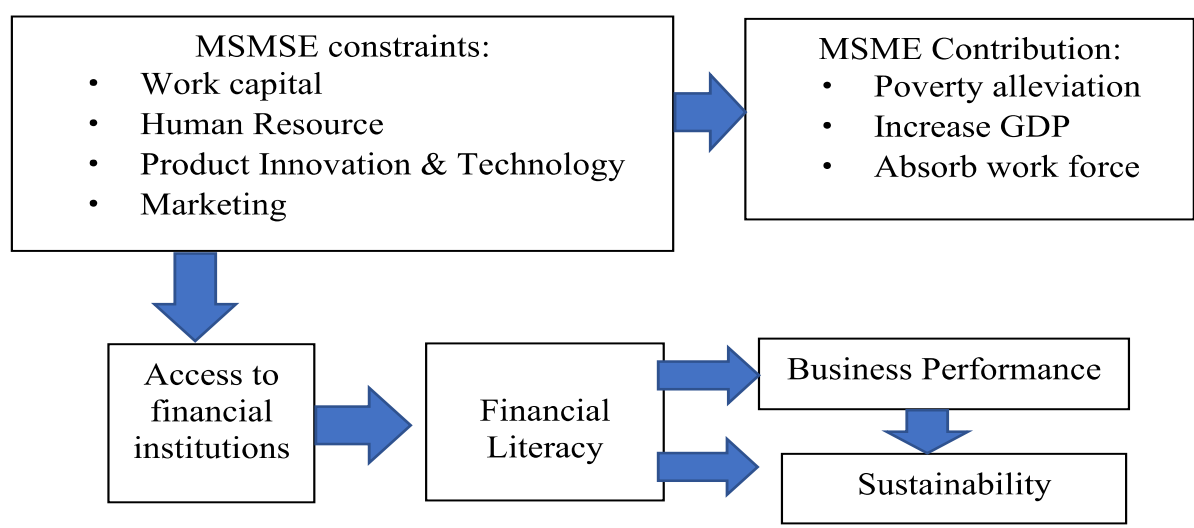

Figure 1. Reseach Framework 
In general, the hypotheses to be tested in this study is as follows which is drawn from the research model depicted in Figure 2 below:

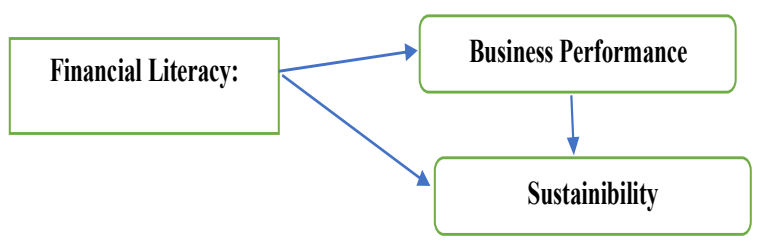

Figure 2. Research Model

H1: Financial literacy has a significant effect to performance of culinary MSME in Greater Jakarta

H2: Financial literacy has a significant effect to sustainability of culinary MSME in Greater Jakarta.

H3: Performance has a significant effect to sustainability of culinary MSME in Greater Jakarta

\section{METHOD}

The object or respondents of this study are individuals who understand and participate in the strategic development process of the company. At MSME, the owner relatively takes a role in strategic decisions. However, it does not rule out the possibility of a manager who is also a person in charge of some MSMEs. One sample represents one MSME. The MSME must have conducted its business at least three (3) years. Samples in the study came from five cities, namely Jakarta, Bogor, Depok, Tangerang and Bekasi.

The primary data collection method was carried out using a face-to-face and online questionnaire with 100 respondents.

The questionnaire consisted of demographic questions and structured research questions. Structured questions consist of three categories of questions, the first is a quiz type modified from the Basic Indonesian Financial Literacy Index (Definit, OJK and USAID, 2013:40) to find out financial literacy at MSME. While the second category is the modification of the EFQM Excellence Model for performance measurement based on the perception of how far the respondent reaches the indicator of business results modified with a Likert-type and measurement scale $5(1=$ no evidence $/$ don't know, $2=$ we have plans $3=$ on our way, $4=$ close to good and $5=$ fully done). While the third category of business sustainability will be modified from the Triple bottom line (TBL) reporting indicator which is measuring how far respondents maintain the continuity of business operations both in terms of economic, social and environmental (ecological). Answers to questions will be given on a scale of 1 to $5(1=$ strongly disagree and $5=$ strongly agree).

The collected data was analyzed using the structural equation model based on Partial Least Square (PLS). It is a powerful analysis method because it can be applied at all data scales, it does not require a lot of assumptions and the sample size does not have to be large. PLS can be used as a confirmation of theory and to build relationships that do not have a basic theory yet or for testing propositions. PLS can also be used for structural modeling with reflective or formative indicators (Jaya \& Sumertajaya, 2008: 118). Descriptive analysis is used to interpret respondents' data, while structural equation models are used to test hypotheses. Financial literacy indicators are thought to affect business performance and stability.

\section{RESULT}

\section{Descriptive Analysis of Respondent Characteristics}

The number of respondents in five cities namely Jakarta, Bogor, Depok, Tangerang and Bekasi 
are 100 people and 20 respondents are taken equally in each city. Based on sex, the percentage of male and female respondents is almost equal, $54 \%$ male and $46 \%$ female. While based on age, the majority $47 \%$ are in group $31-45$ years, while only one person $(1 \%)$ is $>65$ years old, while the remaining $27 \%$ in group $18-30$ years and $24 \%$ in group 46-65 years. It can be said that almost all respondents are still in the productive age, because according to BPS, the productive age group is between 15-64 years.

Based on their educational background, the largest portion is high school education, 30\% and the rest has elementary school education is $14 \%$ and junior high school is $23 \%$. While the respondents who went to college both diplomas and scholars is $22 \%$. It appears that the level of education of respondents in this study is quite diverse.

The division of culinary business types of respondent in this study is grouped based on the scope and development focus of culinary subsector compiled by the Study Team of Indonesian Ministry of Creative Economy Tourism (Lazuardi \& Triadi, 2015:9). The following is the distribution and results obtained: a) Culinary Services as providers of food and/or beverages visited by consumers, e.g. restaurants, cafes, canteens, etc. is $56 \%$, this group is the largest number; b) Culinary services as providers of food and or beverages that come to consumers such as food catering services, etc. is $27 \%$; c) Culinary goods as providers of food and/or beverages, which are usually packaged products - specialty food/drink, for example typical food of certain regions, etc. is $17 \%$.The MSME criteria based on assets and turnover according to the Indonesian Banking Development Institute (LPPI) and Bank Indonesia in 2015, most of the respondents have a micro business size. While the smallest percentage is in the medium business group. More complete results of the grouping can be seen in Table 1 below:

Respondent's acknowledgment of operating profit for the past year was grouped into increasing, constant or decreasing. Most respondents admitted that their business income is fix at $43 \%$, followed by increase at $39 \%$ and finally decrease by $18 \%$. However, all components of respondents' characteristics from city location, gender, age, education, type of culinary business, business size and profit are not used in the measurement of dependent or independent variables.

\section{Analysis of Structural Equation Models Validity and reliability test}

Analysis of structural equation model in this study uses Partial Least Square with SmartPLS software program version 3.2.8. The first step taken is to test the validity and reliability of the three research variables (constructs), namely financial literacy, performance and sustainability. The validity test of convergent indicator reflective with the PLS

Table 1. Percentage of MSME Criteria Based on Asset and Turnover

\begin{tabular}{lcccc}
\hline \multicolumn{1}{c}{ Business Size } & Asset (Rp) & $\mathbf{\%}$ & $\begin{array}{c}\text { Turnover } \\
(\mathbf{R p})\end{array}$ & $\mathbf{\%}$ \\
\hline Micro & Max 50 M & 56 & Max 300 M & 58 \\
Small & $>50 \mathrm{M}-500 \mathrm{M}$ & 29 & $>300 \mathrm{M}-2.5 \mathrm{~B}$ & 31 \\
Medium & $>500 \mathrm{M}-10 \mathrm{~B}$ & 15 & $>2.5 \mathrm{~B}-50 \mathrm{~B}$ & 11 \\
\hline
\end{tabular}

Source: Processed Data (2018) 
program can be seen from the loading factor for each construct indicator. The rule of thumb that is usually used to assess convergent validity is that the loading factor value must be more than 0.7 for confirmatory research and 0.6-0.7 for explanatory research and $>0.5$ is still considered sufficient for early stage research of developing measurement scale (Ghozali, 2015).
As for the reliability test when outer loading is $>0.7$. The results of loading factors from the evaluation of measurement model (outer model) to test the validity and reliability of research indicators are shown in Table 2. It can be seen from the Table 2 that all research indicators are worth more than 0.7 so that they are valid and reliable.

Table 2. Loading Factor of Research Indicator

\begin{tabular}{|c|c|c|}
\hline Indicator & Score & Valid \& Reliable \\
\hline \multicolumn{3}{|l|}{ Financial Literacy } \\
\hline Requirement of ID & 0,868 & Yes \\
\hline Minimum balance of saving account & 0,890 & Yes \\
\hline Deposit guaranteed by government & 0,743 & Yes \\
\hline Simple interest & 0,830 & Yes \\
\hline Compounded interest & 0,829 & Yes \\
\hline Calculate interest on loan & 0,789 & Yes \\
\hline Discount & 0,875 & Yes \\
\hline Time value of money & 0,820 & Yes \\
\hline Money illusion & 0,831 & Yes \\
\hline \multicolumn{3}{|l|}{ Performance } \\
\hline We measure our financial health with an appropriate set of indicators. & 0,814 & Yes \\
\hline We have indicators measuring our market and sales performance & 0,818 & Yes \\
\hline We have indicators to measure our productivity and our overall operational & 0761 & Yes \\
\hline We have indicators to measure our innovation performance & 0,829 & Yes \\
\hline We have positive trends over the past three years for the indicators & & \\
\hline measuring our business results. & 0,821 & Yes \\
\hline $\begin{array}{l}\text { We achieve the quantitative goals we set for the indicators measuring our } \\
\text { business results. }\end{array}$ & 0,733 & Yes \\
\hline $\begin{array}{l}\text { We compare our performance with benchmarks for the indicators measuring } \\
\text { our business results. }\end{array}$ & 0,795 & Yes \\
\hline We understand the rationale behind the evolution of the indicators & 0799 & Yes \\
\hline We measure our financial health with an appropriate set of indicators. & 0,814 & Yes \\
\hline We have indicators measuring our market and sales performance & 0,818 & Yes \\
\hline $\begin{array}{l}\text { We have indicators to measure our productivity and our overall operational } \\
\text { performance. }\end{array}$ & 0,761 & Yes \\
\hline We have indicators to measure our innovation performance & 0,829 & Yes \\
\hline \multicolumn{3}{|l|}{ Sustainability } \\
\hline Economic dimension & 0,700 & Yes \\
\hline Environmental dimension & 0,840 & Yes \\
\hline Social dimension & 0,886 & Yes \\
\hline
\end{tabular}

Source: Processed statistic data 


\section{Regression Test}

Evaluation of the Inner Model R-Square Analysis based on data processing with PLS gives result coefficient of determination ( $\mathrm{R}$ square) for financial literacy on performance is 0.153. It means the magnitude of the effect of financial literacy to performance at MSME is $15.3 \%$ while $84,7 \%$ is affected by other factors that also affect the performance of MSME in Greater Jakarta. It also explains that financial literacy to business sustainability provides an $\mathrm{R}$ square value of 0.051 which means that the magnitude of the effect of financial literacy to business sustainability at MSME in Greater Jakarta is only $5.1 \%$. While the R-square of performance to sustainability is 0.109, which means that the effect of performance to sustainability is $10.9 \%$ and the rest is by other factors.

\section{Hypothesis Test}

A variable is said to have a significant effect on other variables if the value of $t$-count is greater than t-table (significant $5 \%$ ) which is 1.96 or p-value less than 0.05. In Table 3 we can see the path coefficient results from SmartPLS output after the model is bootstrapped. Furthermore, the model can be seen clearly in Figure 3 PLS Output. It can be seen that financial literacy has a significant effect to performance but not to sustainability and performance has a significant effect to sustainability.

From the data of path coefficient above for testing hypothesis 1 , which is financial literacy has a significant effect to the performance of culinary MSME in Greater Jakarta, this hypothesis is accepted. This means

\section{Table 3. Path Coefficient Value}

\begin{tabular}{lllll}
\hline Variables & $\begin{array}{l}\text { Original } \\
\text { Sample }\end{array}$ & $\begin{array}{l}\text { T } \\
\text { Stat- }\end{array}$ & $\begin{array}{l}\text { P } \\
\text { Val }\end{array}$ & Note \\
\hline Financial Literacy to Performance & 0.391 & 5.263 & 0.000 & Sig \\
Financial Literacy to Sustainability & -0.118 & 1.074 & 0.283 & No sig \\
Performance to Sustainability & -0.265 & 2.801 & 0.005 & Sig \\
\hline
\end{tabular}

Source: Processed statistic data

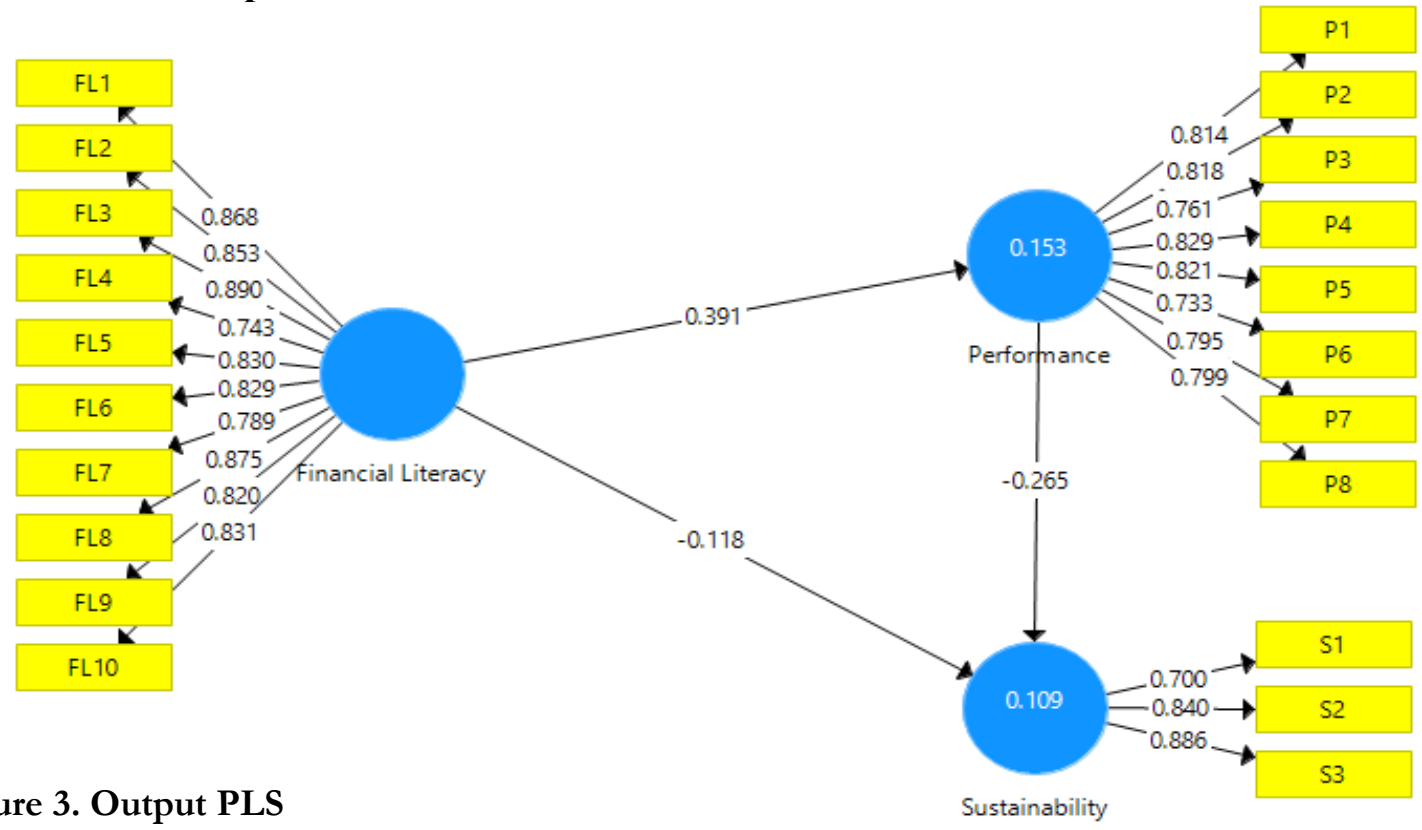

Figure 3. Output PLS 
that the higher the level of financial literacy of MSME, the higher the business performance. Likewise, the third hypothesis is that MSME performance has a significant effect to the sustainability of culinary MSME in Greater Jakarta. This means that the better the business performance of the culinary MSME, the more sustainable the business will be. However, the second hypothesis which is financial literacy has a significant effect to the sustainability of culinary MSME in Greater Jakarta is rejected. In other words, the higher level of financial literacy does not necessarily increase the sustainability of MSME businesses.

\section{DISCUSSION}

Based on statistical tests with SEM model, PLS approach, it was found that some of the results of this study confirm the results of previous studies. The similarity of the test results in the first hypothesis which is financial literacy affects to performance of MSME. This means that MSME need to increase their level of financial literacy because this will affect the level of performance of their business results. Good performance is the main hope for business people. This result, financial literacy affects to performance of MSME, is in line with previous studies conducted domestically by Aribawa (2016) as well as Rahayu \& Musdalifah (2017). Their researches respectively were conducted in Central Java and Surabaya, using the same method SEM Model with PLS approach. This result is also in line with the researchers conducted abroad, in the United States by Dahmen \& Rodriguez (2014) on the urgency of financial literacy for the finances of a small business, and in UK by Adomako \& Danso (2016) about Financial Literacy and Firm Performance.
Dahmen \& Rodriguez (2014) found a strong association between the small business (MSMSE) financial strength and the business owner's habits of mind with regard to their financial statements. Finally, their study clearly suggests that small business owners will be advised to master financial literacy, including the financial ratios that allow an understanding of their financial statements. While Adomako (2016) used a survey-based approach and employing OLS, he examined 298 entrepreneurial firms operating Ghana, a subSaharan African country. His findings indicate that financial literacy improves firm performance and particularly so when resources are flexible, entrepreneurs are able to access finance with ease.

From those conclusions of those studies, it can be assumed that through financial literacy, MSME will more easily overcome obstacles in managing a business, one of which is working capital. With financial literacy, he will understand how to access financial institutions such as banking and understand the provisions in it such as minimum deposits, deposit guarantees, loan repayment returns, discounts and so on. This knowledge is important for MSME to improve their business performance such as having indicators to measure financial health, market and sales performance, productivity and overall operational performance, innovation performance. Besides that, having a good level of financial literacy will later produce positive trends over the past three years on business results, achieve the quantitative goals, can compare performance with existing benchmarks and understand the rationale behind the evolution of the indicators measuring the business results (performance indicators in EFQM Model)

The second hypothesis test result in this study that financial literacy does not significantly 
affect the sustainability of culinary MSME business. It happens since based on education background, about $52 \%$ of respondents having high school or went to college both diplomas and scholars. It appears that the level of education of respondents in this study is quite high as a culinary SMES manager or owner in Indonesia. According to OJK (2016) some factors influence financial literacy are gender, education background, and income level. Education background effects financial literacy because when someone have high education background then he will have broadened knowledge in managing his resources and will be more familiar with economic terms which is indirectly close to financial literacy terms. Meanwhile, most respondents admitted that their operating profit or business income is not having growth, there are $43 \%$ of them telling that their business just staying flat and even $18 \%$ of them telling that that their business income decreases for the past year. Only 39\% of them telling their business income increases. Therefore, the reason why the result of output PLS in this study shows a small number which is only $5,1 \%$. the effect of financial literacy (related with education background) to sustainability (related with operating profit or business income) is clearly explained.

This result is not in line with previous studies conducted by Wise (2013), Dahmen \& Rodriguez (2014), Adomako \& Danso (2016), Aribawa (2016) and Rahayu \& Musdaifah (2017). Wise (2013) used A structural model to test data from 509 young entrepreneurs in Canada who had received start up loans through their participation in a program by the Canadian Youth Business Foundation. His research found that increases in financial literacy led to more frequent production of financial statements. It found that entrepreneurs who produced financial statements more frequently had a higher probability of loan repayment and a lower probability to close their venture involuntarily, which means the financial literacy effects to the sustainability of start-up business or can be consider as the MSME.

Nevertheless. this result is in line with research conducted by Fitria et al (2018) who examined the effect of financial literacy on the growth and sustainability of handicraft SME businesses in Padang. Her research was to 150 people and hypothesis testing is carried out using Structural Equation Modeling (SEM) analysis with STATA program. The result of this study indicates that financial literacy has a significant effect on growth in SMEs in the handicraft sector in Padang but financial literacy does not affect the sustainability of SMEs in the handicraft sector in Padang.

However, if the performance variable is tested its effect on the sustainability variable, it is significant. It means the better the business performance as measured by the EFQM Model Business Excellence performance indicators, the better the sustainability of the culinary MSME business in Greater Jakarta. From the three results of the existing hypothesis, it can be assumed that the financial literacy variable has a direct effect on business performance, but does not have a direct effect on business sustainability, but business performance can be an intermediary variable to see its effect on business sustainability because it has a significant effect.

\section{CONCLUSION \& RECOMMENDATION}

Based on the results and discussion previously explained, the conclusions of this research can be stated in simple sentences. It has been proved that financial literacy effects to performance of culinary MSMEs by $15.3 \%$ as well as the 
performance MSMEs effects to sustainability of culinary MSMEs by $10.9 \%$. However, the financial literacy only effect to the sustainability of culinary MSMEs by $5.1 \%$.

After observing and testing the results of the research, general advice can be given to culinary owners or managers of MSME in the Greater Jakarta City to be more literate about financial literacy, follow programs provided by the government, private sector and NGOs in terms of increasing financial management capacity, do not be satisfied and be careful because the challenges of business competition will be more challenging in the future, especially in the era of digital and financial technology which is growing rapidly today. For stakeholders, especially the government and financial institutions, the results of this study can be used as a barometer of the conditions of culinary MSME in Greater Jakarta in terms of financial literacy, performance and sustainability. Culinary MSME empowerment programs especially in terms of access to capital have become an important agenda considering the contribution of culinary MSME to the national economy. Suggestions for further research to examine more deeply for the existing research variables such as financial literacy variables, because in this study which is limitation of this study only cover basic knowledge, it is better for subsequent studies to add intermediate or advanced knowledge with more specific culinary MSME research samples.

\section{ACKNOWLEDGMENT}

This paper is based upon work supported by HSBC Indonesia Research Award 2018 (HIRA 2018) and Internal Research Award from IISMI STIAMI. Any opinions, findings, and conclusions or recommendations expressed in this paper are those of the author(s) and do not necessarily reflect the views of PT Bank HSBC Indonesia."

\section{REFERENCES}

Adomako, S., Danso, A., \& Damoah, J., O. (2016). The Moderating Influence Of Financial Literacy On The Relationship Between Access To Finance And Firm Growth In Ghana. Venture Capital: International Journal of Entrepreneurial Finance, 18(1): 43-61

Aribawa, D. (2016). Pengaruh Literasi Keuangan

Terhadap Performa dan Keberlanjutan UMKM di Jawa Tenga. Siasat Bisnis, 10(1): 1-13.

Aryco, H. (2017). Pentingnya Peran UMKM bagi Perekonomian Indonesia (online) http://internetmarketing.co.id/peranumkm-bagi-perekonomian-indonesia/ accessed 17 August 2018

BPS. (2014). Data UMKM di Indonesia. Jakarta

Dahmen, P., \& Rodriguez, E. 2014. Financial Literacy and the Success of Small Businesses: An Observation from a Small Business Development Center. International Journal of Numeracy, 7(1): 1-12.

Definit-SEADI-OJK. (2013). Developing Indonesian Financial Literacy Index: Final Report. Jakarta: USAID

Depkop. (2012). Perkembangan Data Usaha Mikro, Kecil dan Menengah dan Usaha Besar. www.Depkop.go.id, (1), 2011-2012.

Eniola, A.A., \& Entebang, H. (2016). Financial literacy and SME Firm Performance. International Journal of Research Studies in Management, 5(1): 31-43.

Febriatmoko, B \& Raharjo, ST. (2015). Meningkatkan Kinerja Bisnis Melalui Keunggulan Bersaing Kuliner Khas Semarang. Proceeding 2 nd Conference in 
Business, Accounting and Management. 139-144.

Fitria, M., Yurniwati, Rahman, A. (2018). The Effect of Financial Literacy on Growth and Sustainability of SMEs (Small and Medium Enterprises) in the Handicraft Sector in Padang. International Journal of Progressive Sciences and Technologies (IJPSAT), 10(2): 382393.

Ghazali, I. (2015). Partial Least Squares Konsep, Teknik dan Aplikasi Menggunakan Program Smartpls 3.0. Semarang: Universitas Diponogoro

Jaya, I.G.N.M. \& Sumertajaya, M. (2008). Pemodelan Persamaan Struktural dengan Partial Least Square. Prosiding Seminar Nasional Matematika Dan Pendidikan Matematika. 118-132.

Lazuardi, M \& Triady, M.S. (2015). Creative Economics: National Culinary Development Plan 2015-2019. PT.Republik Solusi.

LPPI \& BI (2015). Business Profile Micro, Small and Medium Enterprise (MSMSE).

Lusardi \& Mitchell. (2013). The Economic Importance of Financial Literacy: Theory and Evidence. Working Paper 18952 Cambridge: National Bureau Of Economic Research.

Manurung, A. H., \& Rizky, L.,T. (2009). Succesful Financial Planner: A Complete Guide. Jakarta: Grasindo.

Manurung, E. M. \& Barlian, I. (2012). From small to significant: Innovation process in small-medium creative businesses. International Journal of Innovation, Management and Technology, 3(6):788-792

Otoritas Jasa Keuangan. (2016). Peraturan Otoritas Jasa Keuangan Tahun 2016 tentang Peningkatan Literasi dan Inklusi Keuangan di Sektor Jasa Keuangan Bagi Konsumen dan/atau
Masyarakat. Jakarta: Kementerian Hukum dan HAM Republik Indonesia Rahayu, A. Y., \& Musdholifah. (2017). Pengaruh Literasi Keuangan terhadap Kinerja dan Keberlanjutan UMKM di Kota Surabaya. Jurnal Ilmu Manajemen, 5(3): $1-7$.

Santoso, B. (2013). Developing Indonesian Financial Literacy Index. DEFINIT.Asia. Jakarta OJK \& USAID

Sarwono, H. A. (2015). Business Profile of Micro, Small and Medium Enterprises (MSME). Bank Indonesia and LPPI, 557

Senova, A., \& Antasova, M. (2015). Business Performance Assessment And The EFQM Excellence Model 2010 (Case Study). Management. 10(1)183190.

Supriyadi. (2013). Concept and Model of Corporate Sustainability Measurement: A Literature Review. STAR - Study \& Accounting Reseach. 10(3):13-28

USAID. (2009). Development of strategy options for SME financial literacy - Final Report.

Wise, S. (2013). The Impact of Financial Literacy on New Venture Survival. International Journal of Business and Management, 8(23): 30-39. 